\title{
2012 Ralph Bunche Scholars Selected to Present Posters
}

$\mathrm{T}$ he following Ralph Bunche Scholars were selected to present their Ralph Bunche Summer Institute research papers in a poster session at the 2012 APSA Annual Meeting in New Orleans, Louisiana.

Desiree Anderson, Randolph-Macon College, "Our Races Do Not Matter Anymore: Americans, United against the War"

Renata Barreto-Montenegro, Reed College, "Assimilation Reconsidered: The Effect of Transnational Network on the Civic Engagement of 1.5 and 2nd Generation Americans"

Angie Bautista-Chavez, Rice University, "Principals and Immigrant Parents: Linking Descriptive Representation and School Policy"

Jasmine Brooks, Augustana College, "A Thin Line Between Love and Hate: The State's Role in Mandating Arrest Policies"

Julia Cramer, James Madison University, "Finding Their Voice: Minority Perceptions of Media Bias and Their Effect on Political Participation"

Angel Mira, University of Notre Dame, "Revisiting Black Poverty: Are Latinos the New Enemy?"

Patricia Posey, University of Florida, "Location Means Participation: An Analysis of the Proportion of Latinos in States and Their Rates of Participation"

Patricia Sidbury, Virginia State University, "Guess Who's Coming to Dinner? An Analysis of the Contact Theory on the Attitudes toward Homosexuals"

Laurie Tumaneng, University of Guam "The ParticipAsian Problem: Exploring Low Political Participation among Asian Americans"

Lonald Wishom, Weber State University, "From Planning a Prom to Having the World in Your Palms: The Link between Student Government and Political Participation"

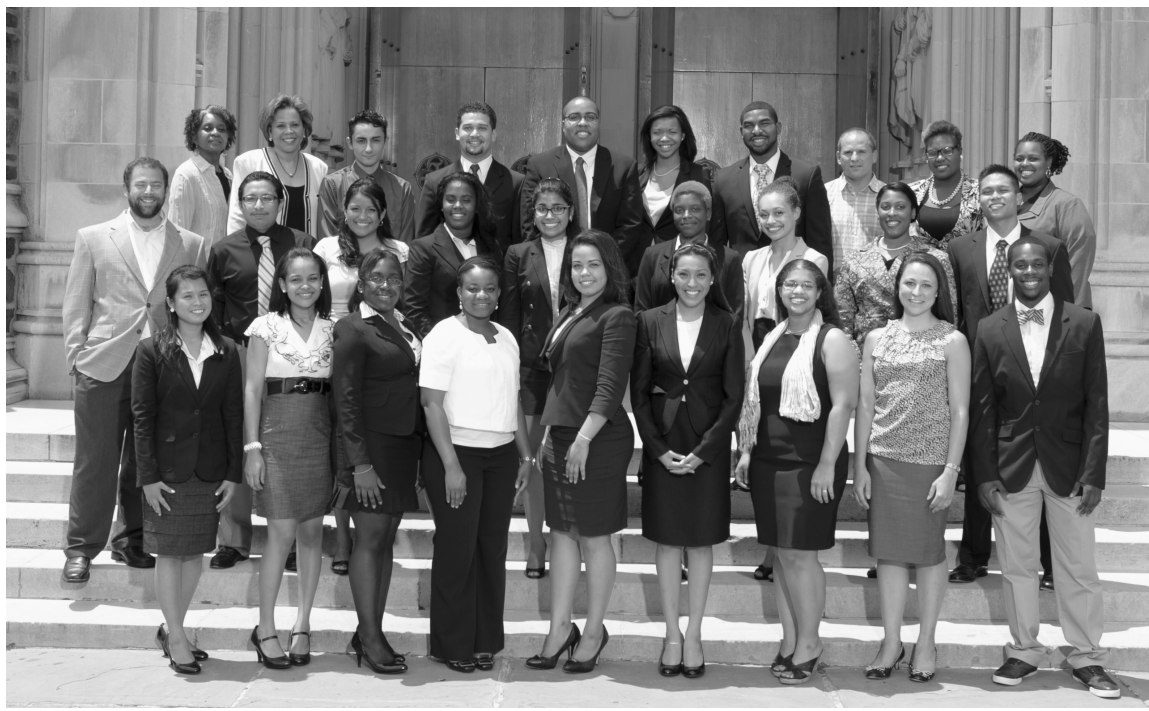

Ralph Bunche The Ralph Bunche Summer Institute participants at Duke University in July 2012. Front row: (right to left) Laurie Tumaneng, Vierka D. Vasquez Lorenzo, Patricia Posey, Gloria Ayee (assistant to the graduate staff assistant), Allyson Shaffier, Angie M. Bautista-Chavez, Jessica D. Carew (teaching assistant), Brittany Perry (teaching assistant), and Lavar Thomas.Second row: (right to left) David Sparks (teaching assistant), Moises H. Marroquin, Julia M. Cramer, Robin R. Campbell, Renata A. Barreto-Montenegro, Maya Randolph, Desiree Anderson, Ashley Blount, and Angel Miguel C. Mira . Third row: (right to left) Doris C. Cross, (assistant to the director), Paula D. McClain (director), Ignacio B. Marquez, Sergio Cisneros, Joshua Branch, Jasmine Brooks, Lonald D. Wishom, II, Patrick Horn (Writing Tutor), Patricia Sidbury, and Taneshia Means (graduate staff assistant). Not Pictured: Scott de Marchi (professor), Christopher DeSante (teaching assistant).

\section{ABOUT THE PROGRAM}

The Ralph Bunche Summer Institute is a five-week program for minority undergraduate students who are interested in pursuing a doctoral degree in political science. APSA initiated the institute in 1986, and since 2000, it has been hosted and cosponsored by Duke University under the direction of professor Paula D. McClain. For more information or to download an application for the 2013 institute, visit www.apsanet.org_content_6602.cfm. 